\title{
Shunt right or left? Decision 2016
}

\author{
Ralph S. Mosca, MD
}

\author{
From the Department of Cardiothoracic Surgery, New York University-Langone Medical Center, New York, NY. \\ Disclosures: Author has nothing to disclose with regard to commercial support. \\ Received for publication Nov 1, 2016; accepted for publication Nov 2, 2016; available ahead of print Jan 10, 2017. \\ Address for reprints: Ralph S. Mosca, MD, New York University-Langone Medical Center, Cardiothoracic Sur- \\ gery, 530 First Ave, Suite 9V, New York, NY 10016 (E-mail: ralph.mosca@nyumc.org). \\ J Thorac Cardiovasc Surg 2017;153:1501-2 \\ $0022-5223 / \$ 36.00$ \\ Copyright (C) 2016 by The American Association for Thoracic Surgery \\ http://dx.doi.org/10.1016/j.jtcvs.2016.11.007
}

The reintroduction of the right ventricle-pulmonary artery (RV-PA) conduit into the neonatal palliation of hypoplastic left heart syndrome ${ }^{1}$ has been reported to improve early survival $^{2}$; however, its effect on right ventricular function and pulmonary artery growth are still debated. ${ }^{3,4}$ The procedure is spatially and geometrically complex, and a number of different techniques have been proffered to optimize pulmonary blood flow and reduce right ventricular injury. Placements of the RV-PA conduit to the left and to the right of the neoaortic reconstruction have been described, along with the benefits and pitfalls of each. ${ }^{5-7}$

In this issue of the Journal, Andersen and colleagues ${ }^{8}$ present a relatively large $(n=274)$ retrospective cohort review of the data available from the National Institutes of Health National Heart, Lung, and Blood Institute Pediatric Heart Network Single Ventricle Reconstruction (SVR) trial, investigating the influence of right- or left-sided shunt placement on survival, reintervention, and pulmonary artery development. Because of a number of differences in the conduct of the operations; most notably, shunt size and length as well as perfusion strategy, a subgroup analysis with propensity-score matching was performed. Placement of the RV-PA conduit to the right of the neoaorta was associated with fewer shunt revisions and improved survival; however, pulmonary artery size, the number of reinterventions, and hemodynamic parameters were not affected by the shunt position.

The subject of this article is important to the surgeon, because the shunt remains the Achilles' heel of the Norwood procedure. Andersen and colleagues ${ }^{8}$ have offered a number of inferences from the available data; however, the SVR trial was not designed to ferret out the effects of shunt "sidedness." The randomization dealt with the dichotomy of the Blalock-Taussig shunt versus the RV-PA shunt. In the SVR public data set, center volume is not provided as a continuous variable, and the patient age and the dates and timing of reinterventions are not consistently reported, restricting the use of more precise statistical methods. The use of propensity matching by Andersen and colleagues ${ }^{8}$ likely limits confounders, but it significantly reduces (by $>50 \%$ ) the sample size and removes

\section{References}

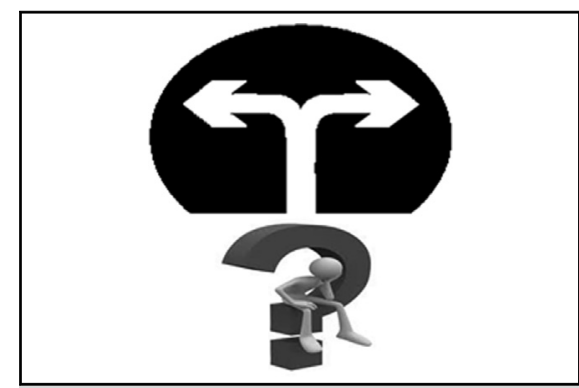

Optimal shunt positioning may depend on techniques of arch and pulmonary artery repair.

\section{Central Message}

Outcomes after the Norwood procedure are likely a product of the complex interplay of the geometry of the aortic arch and pulmonary artery reconstruction as well as the "sidedness" of the Sano shunt.

See Article page 1490.

the majority of patients undergoing a Norwood procedure with circulatory arrest. No reliable data are available concerning the types of shunts or the techniques of the proximal or distal shunt anastomoses. One finding not to be ignored is that the need for a surgical shunt revision was associated with a $42 \%$ mortality. It behooves us to get this correct.

Shunt sidedness will likely prove to be one of many important interrelated factors. A number of new technical modifications to the shunt have evolved since the SVR trial. ${ }^{9-12}$ Limiting the ventriculotomy, using partial or complete rings to support the graft, and the technique of closure of the distal pulmonary artery stump may all prove to be factors. The final stage I reconstruction must exist within the confines of the neonatal mediastinum. Space is at a premium, and pulmonary artery development is no doubt related in each case to the intricacies of the dimensions of the chest and the geometry of the arch reconstruction and pulmonary artery, in addition to the shunt type and position. ${ }^{13-15}$ Future studies will need to consider all these variables. Magnetic resonance imaging and mathematical modeling may be helpful. ${ }^{16,17}$

1. Sano S, Ishino K, Kawada M, Arai S, Kasahara S, Asai T, et al. Right ventriclepulmonary artery shunt in first stage palliation of hypoplastic left heart syndrome. J Thorac Cardiovasc Surg. 2003;126:504-9; discussion 509-10.

2. Ohye RG, Sleeper LA, Mahony L, Newburger JW, Pearson GD, Lu M, et al. Comparison of shunt types in the Norwood procedure for single-ventricle lesions. N Engl J Med. 2010;362:1980-92. 
3. Newburger JW, Sleeper LA, Frommelt PC, Pearson GD, Mahle WT, Chen S, et al. Pediatric Heart Network Investigators. Transplantation-free survival and interventions at 3 years in the single ventricle reconstruction trial. Circulation. 2014;129:2013-20.

4. Raja SG, Atamanyuk I, Kostolny M, Tsang V. In hypoplastic left heart patients is Sano shunt compared with modified Blalock-Taussig shunt associated with deleterious effects on ventricular performance? Interact Cardiovasc Thorac Surg. 2010;10:620-3.

5. Aortic atresia and hypoplastic left heart syndrome. In: Litwin SB, ed. Color atlas of congenital heart surgery. 2nd ed. New York: Springer Publishing; 2007: 402-14.

6. Barron DJ, Brooks A, Stickley J, Wooley SM, Stümper O, Jones TJ, et al. The Norwood procedure using a right ventricle-pulmonary artery conduit: comparison of the right-sided versus left-sided conduit position. J Thorac Cardiovasc Surg. 2009;138:528-37.

7. Gist KM, Barrett CS, Graham DA, Crumback SL, Schuchardt EL, Erickson B, Jaggers J. Pulmonary artery interventions after Norwood procedure: does type or position of shunt predict need for intervention? J Thorac Cardiovasc Surg. 2013; 145:1485-92.

8. Andersen ND, Meza JM, Byler MR, Lodge AJ, Hill KD, Hornik CP, Jaquiss RDB. Comparison of right ventricle -pulmonary artery shunt position in the Single Ventricle Reconstruction trial. J Thorac Cardiovasc Surg. 2017; 153:1490-500.e1.

9. Kolcz J, Skaldzien T, Kordon Z, Rudzinski A, Skalski J. Impact of right ventricle to pulmonary artery conduit placement on pulmonary artery development after the Norwood procedure in hypoplastic left heart syndrome. Eur J Cardiothorac Surg. 2012;42:218-23; discussion 223-4.
10. Schreiber C, Prodan Z, Eicken A, Rüdiger L. Novel modification of right ventricle to pulmonary artery shunt in palliation of hypoplastic left heart syndrome. Ann Thorac Surg. 2007;83:1231; author reply 1231-2.

11. Tweddell JS, Mitchell ME, Woods RK, Spray TL, Quintessenza JA. Construction of the right ventricle to pulmonary artery conduit in the Norwood: the "dunk" technique. Oper Tech Thorac Cardiovasc Surg. 2012;17:81-98.

12. Itatani K, Miyaji K, Qian Y, Lui JL, Miyakoshi T, Murakami A, et al. Influence of surgical arch reconstruction methods on single ventricle workload in the Norwood procedure. J Thorac Cardiovasc Surg. 2012;144:130-8.

13. Nassar MS, Bertaud S, Goreczny S, Greil G, Austin CB, Salih C, et al. Technical and anatomical factors affecting the size of the branch pulmonary arteries following first-stage Norwood palliation for hypoplastic left heart syndrome. Interact Cardiovasc Thorac Surg. 2015;20:631-5.

14. Bruse JL, Cervi E, McLeod K, Biglino G, Sermesant M, Pennec X, et al. Looks do matter! Aortic arch shape following hypoplastic left heart syndrome palliation correlates with cavopulmonary physiology and outcomes. Presented at: 52nd Annual STS Meeting; January 23-27, 2016; Phoenix, AZ.

15. Asada S, Yamagishi M, Miyazaki T, Maeda Y, Kato N, Yaku H. Anatomical predictor of postoperative compression of pulmonary artery after the Norwood procedure without supplemental material. Presented at: 52nd Annual STS Meeting; January 23-27, 2016; Phoenix, AZ.

16. Ntsinjana HN, Hughes ML, Taylor AM. The role of cardiovascular magnetic resonance in pediatric congenital heart disease. J Cardiovasc Magn Reson. 2011;13:51.

17. Jalali A, Jones GF, Licht DJ, Nataraj C. Application of mathematical modeling for simulation and analysis of hypoplastic left heart syndrome (HLHS) in preand postsurgery conditions. Biomed Res Int. 2015;2015:987293. 